\title{
РЕАКЦИИ СОСУДИСТОГО ЭНДОТЕЛИЯ ЧЕЛОВЕКА НА МЕТАБОЛИЧЕСКИЕ НАРУШЕНИЯ ПРИ САХАРНОМ ДИАБЕТЕ 2 ТИПА: РЕЗУЛЬТАТЫ МОДЕЛИРОВАНИЯ IN VITRO
}

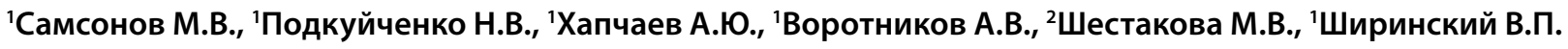 \\ ${ }^{1}$ НИИ экспериментальной кардиологии, НМИЦ кардиологии Минздрава России, Москва \\ ${ }^{2}$ Институт диабета, НМИЦ эндокринологии Минздрава России, Москва
}

На разных стадиях развития сахарного диабета 2 типа (СД2Т) наблюдается повышенный уровень свободных жирных кислот (СЖК), инсулина и глюкозы в крови пациентов. Эти метаболические нарушения связывают с ангиопатиями при СД2Т, но понимание механизмов повреждения сосудов недостаточное. Целью исследования было установление вклада каждого из упомянутых стресс-факторов в развитие дисфункции эндотелия сосудов в плане нарушения его барьерных свойств и синтеза оксида азота (NO).

МАТЕРИАЛЫ И МЕТОДЫ: В Качестве модельНЫХ эндотелиальнЫХ Клеток (ЭК) использовали эндотелий пупочной вены человека (HUVEC), иммортализованный эндотелий из микрососудов человека (TIME) и линейные ЭК ЕА.hy926. ЭК культивировали в течение 3-14 суток в присутствии 0,8 мМ пальмитата, 100 нМ инсулина или 30 мМ глюкозы, моделируя метаболические нарушения при СД2Т. Дополнительно ЭК обрабатывали малоновым диальдегидом (МДА) — продуктом перекисного окисления липидов, а также метилглиоксалем (МГО) и глиоксалем (ГО) - продуктами окислительных превращений глюкозы. Состояние эндотелиального барьера оценивали по уровню его электрического импеданса с помощью прибора ECIS-z (Applied BioPhysics, CША) и по скорости диффузии ФИТЦ-декстрана через эндотелиальный монослой. Синтез NO и продукцию активных форм кислорода (АФК) измеряли с помощью флуоресцентных индикаторов DAF-FM и DCF-DA соответственно. Модификацию эндотелиальных белков МДА и МГО выявляли с помощью специфических антител методом иммуноблоттинга. Этим же методом анализировали внутриклеточный сигнальный каскад инсулинового рецептора, используя фосфоспецифические антитела к компонентам этого каскада.

РЕЗУЛЬТАТЫ: экспериментальная гиперлипидемия, в отличие от гиперинсулинемии и гипергликемии, вызывает гибель ЭК на 3-5-е сутки культивирования. Подобные эффекты при гипергликемии наблюдаются значительно позднее. Добавление к среде культивирования карнитина, способствующего транспорту СЖК в митохондрии и их $\beta$-окислению с образованием АТФ, улучшает выживаемость эндотелия и сохраняет его барьерные свойства. Более того, пальмитат первоначально укрепляет барьер за счет стимуляции эндотелиальной NO-синтазы (eNOS), однако в дальнейшем он стимулирует накопление АФК и МДА-модифицированных белков. Это приводит к снижению барьерных свойств эндотелия за счет нарушения ламеллиподиальной подвижности и контактных взаимодействий ЭК. Митохондриальный антиоксидант SkQ1 снижает уровень АФК и МДА-модифицированных белков в ЭК. Избыточный пальмитат нарушает активацию еNOS инсулином за счет подъема базового уровня синтеза NO без очевидного воздействия на сигнальный каскад инсулинового рецептора. При воздействии на ЭК экзогенного МДА эндотелиальный барьер нарушается, базовый уровень NO снижается, и активации еNOS инсулином также не происходит. Падает фосфорилирование компонентов сигнального каскада инсулинового рецептора, т.е. ухудшается проведение внутриклеточного сигнала от инсулина к еNOS. MГO не влияет на эндотелиальный барьер, регуляцию eNOS инсулином и продукцию NO.

Выводы: по данных моделирования in vitro, из основных метаболических нарушений, характерных для СД2Т, наиболее серьезное негативное воздействие на эндотелий оказывает высокий уровень СЖК (пальмитата). Пальмитат вызывает накопление в ЭК продуктов перекисного окисления липидов, которые приводят к эндотелиальной дисфункции и нарушению регуляции ЭК инсулином. Учитывая более раннее возникновение дислипидемических нарушений, чем гипергликемии, при развитии СД2Т, в формировании диабетической ангиопатии может преобладать липотоксический компонент.

Поддержано грантом РНФ № 19-15-00361.

КЛЮЧЕВЫЕ СЛОВА: эндотелиальный барьер; сахарный диабет 2 типа; свободные жирные кислоты; гипергликемия; инсулиновая сигнализация; оксид азота; дикарбонильный стресс. 